\title{
Antifungal Activity of Purified Hydrolase Complex from Trichoderma hamatum
}

\author{
V. O. Okwusogu ${ }^{1}$, A. A. Onilude ${ }^{1}$ and O. H. Raji ${ }^{2}$ \\ ${ }^{1}$ (Department of Microbiology, University of Ibadan, Ibadan, Oyo State, Nigeria) \\ ${ }_{2}^{2}$ (Department of Food Technology, Moshood Abiola Polytechnic, Ogun State, Nigeria
}

\begin{abstract}
The use of chemical compounds to eradicate plant pathogens proved successful but the toxicological and environmental effects of these chemical compounds have been of great concern. However, there is the need for an alternative that is eco friendly. This work aimed at isolating Trichoderma species that has the potential to eradicate plant pathogens. Trichoderma hamatum was isolated from decayed wood sample and the production of hydrolytic enzymes from it was carried out using submerged fermentation under static and shaking incubation conditions. The enzymes produced were tested singly and in combination for their abilities to reduce the growth of pathogenic fungi (Aspergillus niger, Aspergillus flavus, Aspergillus terrus and Fusarium oxysporum). The enzymes were purified and the activities of the three enzymes produced were maximal on the third day of incubation. All enzymes (crude and partially purified) singly and in combination successfully reduced the growth of the test isolates. The partial purification of the enzymes using ammonium sulphate precipitation result in increase in the enzyme activities.
\end{abstract}

Keywords: Antifungal, Hydrolase, Submerged fermentation, Test organisms, Trichoderma hamatum.

\section{Introduction}

Soil borne pathogens annually create major economical losses in many important crops. The use of chemical compounds to eradicate plant pathogens proved successful but the toxicological and environmental effects of these chemical compounds have been of great concern. Also, the high cost associated with the use of chemicals to control diseases caused by these pathogens is a limiting factor in the profitability of crop production[1]. These have led to drastic reduction in the availability of efficient chemical compound and appearance of new strains of pathogens. Hence, there is a need for a alternative that is eco-friendly.

Fungi are known to be biocontrol agents that secrete a wide array of enzymes that have been found very useful in preventing plant pathogens. Biological controls of plant diseases have been found as an alternative to the use of chemical compounds to control plant pathogens because it is cost effective, environmentally safe and once established, persists in the soil for a longer period and offers disease protection even in consecutive crop seasons[2].

The genus Trichoderma, a saprophytic fungus found in almost all soil, possess the ability to act as a biocontrol agent against fungal diseases of plant [3, 4]. The antifungal activity displayed by Trichoderma species against phytopathogenic fungi is as a result of multidegradation of the cell walls of the fungal host in the process of mycoparasitism[5]. Trichoderma produces an array of enzymes which are industrially important. Several works have been carried out on enzyme production by Trichoderma spp. For example, exo- $\beta-1-3$-glucanase has been produced from Trichoderma reesei[6]; exo- $\beta-1-3$-glucanase and cellulase have been produced from Trichoderma viride [7,8]; protease, cellulase, endo- $\beta$-1-3-glucanase and chitinase have also been produced from Trichoderma harzianum $[9,10,11,12]$. Xylanase was also produced from Trichoderma longibratum[13].

\subsection{Samples collection}

\section{Materials And Methods}

\subsubsection{Sample}

Soil samples were collected from the nursery of the Department of Microbiology, University of Ibadan and National Institute of Horticulture (NIHORT), Jericho, Ibadan, Oyo State. Decayed wood samples were collected from a decaying felled tree in front of Environmental Microbiology Laboratory, University of Ibadan using a sterile container and brought to the laboratory for analysis within 24 hours.

\subsubsection{Test Organism}

Aspergillus flavus and Fusarium oxysporum were obtained from the culture of collection of the Microbial Physiology and Biochemistry Laboratory, Department of Microbiology, University of Ibadan. Aspergillus niger were obtained from International Institute of Tropical Agriculture (IITA) Moniya, Ibadan. Aspergillus terrus was obtained from Kappa Scientific Institute, Trans Amusement Park, Bodija Ibadan. The organisms were maintained on Potato Dextrose Agar slants and preserved at $4^{\circ} \mathrm{C}$. 


\subsection{Isolation of Organisms}

Standard suspensions of the samples were prepared by dissolving 1 gram of each sample in 10mls of sterile distilled water. Different ten-fold dilutions were prepared from the stock solution according[14] and plated out in duplicate on Potato Dextrose Agar containing 50ppm streptomycin using pour plate method and incubated at $30^{\circ} \mathrm{C}$ for 5 days. The organisms were subcultured to obtain pure cultures which were maintained on Potato Dextrose Agar slants and preserved at $4^{\circ} \mathrm{C}$.

\subsection{Identification of Isolates}

The isolated fungi were identified according to their micro-morphology, colour and morphology of the sporulating structures[14].

\subsection{Inoculum preparation} slant[15].

Inoculum was prepared by adding $10 \mathrm{ml}$ of distilled water with $0.1 \%$ Tween 80 to the isolate on an agar

\subsection{Enzyme Production and Assay}

2.5.1 Celluase

Cellulase was produced in a medium containing (g/l; w/v): $\left(\mathrm{NH}_{4}\right)_{2} \mathrm{SO}_{4}, 1.4$; Urea, 0.3; $\mathrm{KH}_{2} \mathrm{PO}_{4}, 2.0$; $\mathrm{MgSO}_{4} .7 \mathrm{H}_{2} \mathrm{O}, 0.3 ; \mathrm{CaCl}_{2}, 0.3$; yeast extract, $0.1[16]$ and assayed[17].

\subsubsection{Amylase}

Amylase was produced in a medium containing (g/l; w/v): $\mathrm{NH}_{4} \mathrm{NO}_{3}, 10 ; \mathrm{KH}_{2} \mathrm{PO}_{4}, 1.4 ; \mathrm{MgSO}_{4} .7 \mathrm{H}_{2} \mathrm{O}$,

$0.1 ; \mathrm{KCl}, 0.5$; starch, 20[18] and assayed[19].

\subsubsection{Protease}

Protease was produced in Czapek-Dox medium[20] and assayed using the method of Kunitz[21].

\subsection{Protein Estimation}

The protein estimation of the enzymes' filtrates were carried out according to the method of Lowry[22]

\subsection{Enzymes purification}

The crude enzymes were precipitated using ammonium sulphate[23]

2.8 Antagonistic activity assay of the crude and purified enzymes of Trichoderma hamatum against the test isolates

The antagonistic activity of the crude and purified enzymes were tested against different fungal isolates according to the method of Negash[24] and the mycelial growth reduction determined according to the formula: Mycelial growth reduction $=\mathrm{Co}-\mathrm{T}[25,26]$; where $\mathrm{Co}$ is the radial growth measurement of the test isolate in the control plate; $\mathrm{T}$ is the radial growth measurement of the test isolate in the test plate.

\section{Results}

The organism isolated grew in a circular pattern with the conidial area whitish green and no discoloration of the media was observed. The organism was identified to be Trichoderma hamatum.

Table 1 and Table 2 show the effect of time of incubation on the production of enzymes using two different incubation conditions (shaking and static). Amylase increased progressively with time under shaking condition while it attained its maximum activity at 48hours under the static condition. Cellulase produced under both incubation conditions increased progressively while Protease activity reached its maximum at 72 hours and then begins to decrease

TABLE 1 Effect of time of incubation on the activity (Units/ml) of the enzymes produced under shaking incubation condition

\begin{tabular}{cccccc}
\hline Time (hour) & Amylase & Cellulase & Protease & \\
\hline 24 & $0.107 \pm 0.00$ & $0.0001 \pm 0.00$ & $0.00123 \pm 0.00$ & \\
48 & $0.24 \pm 0.01$ & $0.0006 \pm 0.00$ & - & \\
72 & $0.28 \pm 0.01$ & $0.0051 \pm 0.00$ & $0.0186 \pm 0.00$ & \\
120 & - & - & $0.0163 \pm 0.00$ & & \\
168 & - & - & $0.0123 \pm 0.00$ & & \\
Note: & each & value $\quad$ is & the & mean & value \pm standard error of mean
\end{tabular}

- means no assay of enzyme activity 
TABLE2 Effect of time of incubation on the activity (Units/ml) of the enzymes produced under static incubation condition

\begin{tabular}{cccccc}
\hline Time (hour) & Amylase & Cellulase & Protease & \\
\hline 24 & $0.026 \pm 0.00$ & $0.0003 \pm 0.00$ & $0.00123 \pm 0.00$ & \\
48 & $0.24 \pm 0.01$ & $0.0026 \pm 0.00$ & - & & \\
72 & $0.214 \pm 0.00$ & $0.0062 \pm 0.00$ & $0.0163 \pm 0.00$ & \\
120 & - & - & $0.015 \pm 0.00$ & & \\
168 & - & - & $0.005 \pm 0.00$ & & \\
Note: & each & value is the mean & value \pm & standard & error \\
& - means no assay of enzyme activity & & & &
\end{tabular}

Table 3 and 4 show the effect of time of incubation on the dry mycelial weight obtained during enzyme production by Trichoderma hamatum under two different incubation conditions. The dry mycelia weight obtained during the production of amylase and cellulase increased with time while the dry mycelial weight of protease increased but decreased after 72 hours for both incubation conditions.

TABLE3 Effect of time of incubation on the dry mycelial weight $(\mathrm{g})$ obtained during enzymes production by Trichoderma hamatum under shaking incubation condition

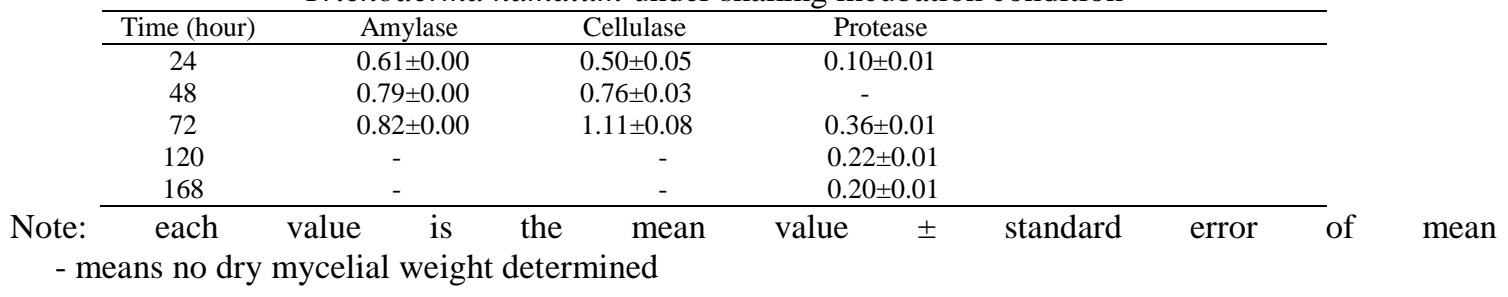

TABLE4 Effect of time of incubation on the dry mycelial weight (g) obtained during enzymes production by Trichoderma hamatum under shaking incubation condition

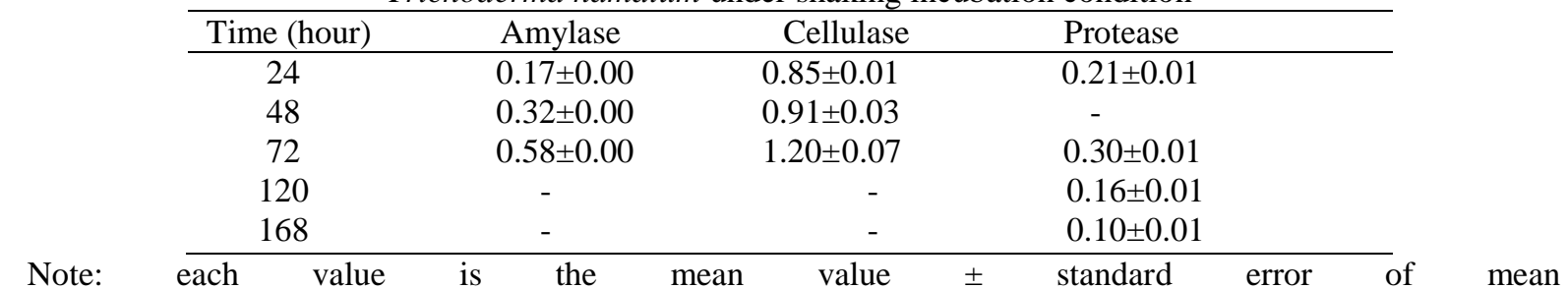

- means no dry mycelial weight determined

Table 5 and 6 show the effect of time of incubation on the protein content of the enzyme produced by Trichoderma hamatum. The protein content of amylase and cellulase produced under shaking incubation condition increases with time while that of the static incubation condition also increases but decreases at 72hours. The protein content of protease also increases with time but decreases at 168 and 120 hours respectively.

TABLE5 Effect of time of incubation on the total protein content $(\mathrm{mg} / \mathrm{ml})$ of the enzymes produced by

Trichoderma hamatum under shaking incubation condition

\begin{tabular}{|c|c|c|c|}
\hline Time (hour) & Amylase & Cellulase & Protease \\
\hline 24 & $0.25 \pm 0.01$ & $0.16 \pm 0.01$ & $0.25 \pm 0.01$ \\
\hline 48 & $0.31 \pm 0.01$ & $0.22 \pm 0.01$ & - \\
\hline 72 & $0.45 \pm 0.02$ & $0.32 \pm 0.03$ & $0.33 \pm 0.02$ \\
\hline 120 & - & - & $0.23 \pm 0.01$ \\
\hline 168 & - & - & $0.19 \pm 0.01$ \\
\hline
\end{tabular}

- means no dry mycelial weight determined

TABLE6 Effect of time of incubation on the total protein content $(\mathrm{mg} / \mathrm{ml})$ of the enzymes produced by

Trichoderma hamatum under static incubation condition

\begin{tabular}{cccc}
\hline Time (hour) & Amylase & Cellulase & Protease \\
\hline 24 & $0.36 \pm 0.04$ & $0.08 \pm 0.01$ & $0.29 \pm 0.01$ \\
48 & $0.41 \pm 0.06$ & $0.23 \pm 0.02$ & - \\
72 & $0.30 \pm 0.08$ & $0.09 \pm 0.01$ & $0.35 \pm 0.01$ \\
120 & - & - & $0.23 \pm 0.01$ \\
168 & - & - & $0.19 \pm 0.01$ \\
\hline
\end{tabular}


Note: each value is the mean value \pm standard error of mean - means no dry mycelial weight determined

The ammonium sulphate precipitation of the enzymes produced gave 1.15, 1.26 and 1.10 folds increase in the activities of amylase, cellulase and protease respectively.

Tables $7-12$ show the antagonistic activity assay of the crude culture filtrates and partially purifies enzymes of Trichoderma hamatum against the test isolates.

TABLE7 Mycelial growth reduction ( $\mathrm{mm}$ ) of the Aspergillus flavus by the crude filtrate (singly and in combination) of Trichoderma hamatum Incubation period (days)/mycelial growth (mm)

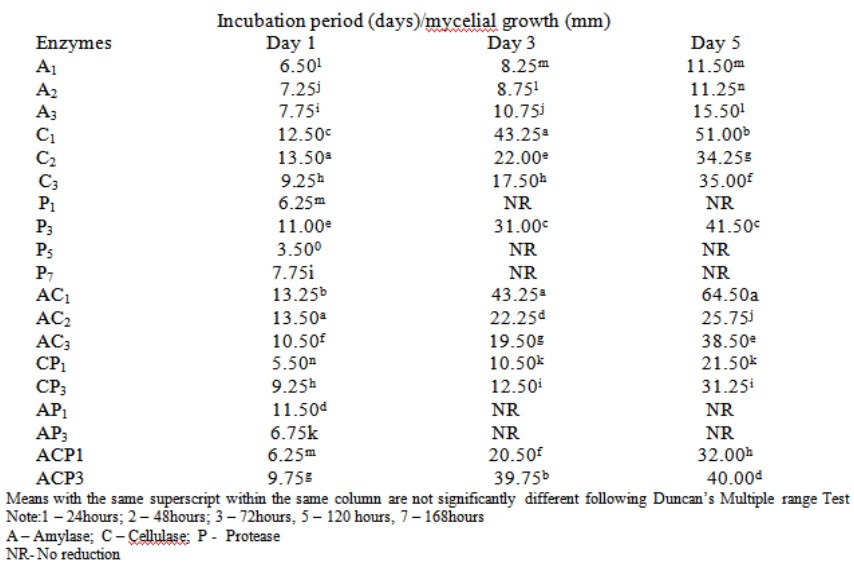

TABLE8 Mycelial growth reduction ( $\mathrm{mm}$ ) of the Fusarium oxysporum by the crude filtrate (singly and in combination) of Trichoderma hamatum

\begin{tabular}{|c|c|c|c|}
\hline \multicolumn{4}{|c|}{ Incubation period (days)/mycelial growth (mm) } \\
\hline Enzymes & Day 1 & Day 3 & Day 5 \\
\hline $\mathrm{A}_{1}$ & NR & NR & $\mathrm{NR}$ \\
\hline $\mathrm{A}_{2}$ & $2.50^{\mathrm{m}}$ & $0.50^{2}$ & $\mathrm{NR}$ \\
\hline$A_{3}$ & $5.00 \mathrm{~g}$ & $2.50^{\mathrm{b}}$ & NR \\
\hline $\mathrm{C}_{1}$ & $3.00^{\mathrm{k}}$ & $0.50^{\circ}$ & NR \\
\hline $\mathrm{C}_{2}$ & NR & NR & NR \\
\hline $\mathrm{C}_{3}$ & $2.75^{1}$ & NR & NR \\
\hline $\mathrm{P}_{1}$ & $3.00^{\mathrm{k}}$ & NR & NR \\
\hline $\mathrm{P}_{3}$ & $8.00^{\circ}$ & $4.25^{\mathrm{a}}$ & NR \\
\hline $\mathrm{P}_{5}$ & $3.25 \mathrm{j}$ & $1.50^{\mathrm{d}}$ & NR \\
\hline $\mathrm{P}_{7}$ & $3.50^{\mathrm{i}}$ & NR & NR \\
\hline $\mathrm{AC}_{1}$ & $4.75^{\mathrm{h}}$ & NR & NR \\
\hline $\mathrm{AC}_{2}$ & $1.00^{\mathrm{n}}$ & NR & NR \\
\hline $\mathrm{AC}_{3}$ & NR & NR & NR \\
\hline $\mathrm{CP}_{1}$ & $6.50^{f}$ & NR & NR \\
\hline $\mathrm{CP}_{3}$ & $8.50^{\mathrm{d}}$ & $1.50^{\mathrm{d}}$ & NR \\
\hline $\mathrm{AP}_{1}$ & $9.00^{\mathrm{c}}$ & $2.50^{\mathrm{b}}$ & NR \\
\hline $\mathrm{AP}_{3}$ & $1.00^{\mathrm{n}}$ & NR & NR \\
\hline
\end{tabular}

TABLE9 Mycelial growth reduction ( $\mathrm{mm}$ ) of the Aspergillus niger by the crude filtrate (singly and in combination) of Trichoderma hamatum

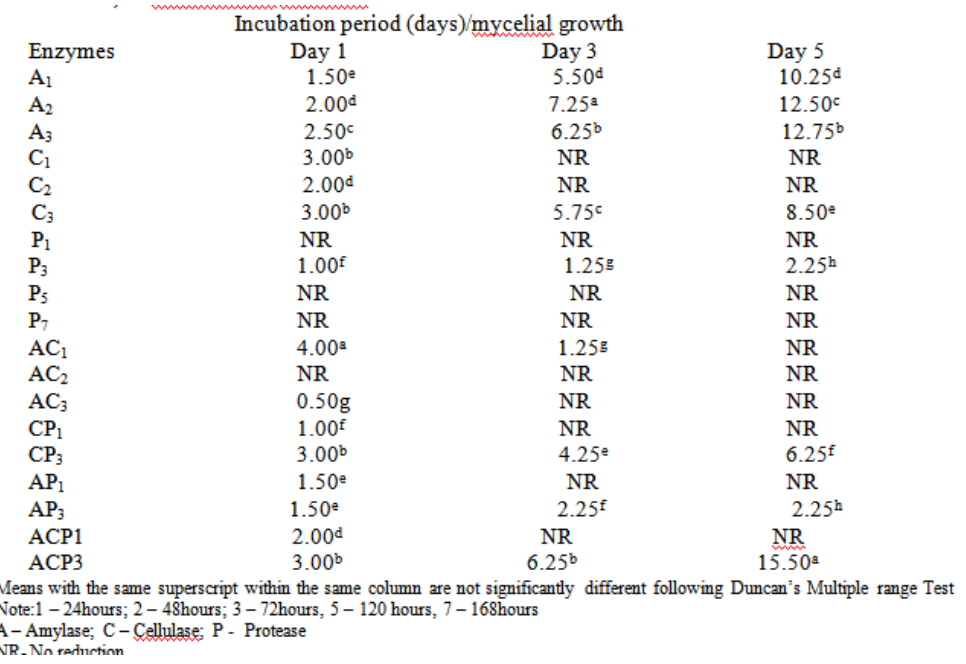


TABLE10 Mycelial growth reduction (mm) of the Aspergillus flavus by the partially purified enzymes (singly and in combination) of Trichoderma hamatum

\begin{tabular}{cccc}
\hline & \multicolumn{3}{c}{ Incubation period (days)/mycelia growth $(\mathrm{mm})$} \\
Enzymes & Day1 & Day 3 & Day 5 \\
\hline A & $0.50^{\mathrm{b}}$ & $4.25^{\mathrm{d}}$ & $12.50^{\mathrm{g}}$ \\
C & $1.50^{\mathrm{a}}$ & $7.50^{\mathrm{b}}$ & $28.50^{\mathrm{c}}$ \\
P & $\mathrm{NR}$ & $\mathrm{NR}$ & $20.00^{\mathrm{e}}$ \\
AC & $\mathrm{NR}$ & $2.75^{\mathrm{f}}$ & $17.50^{\mathrm{f}}$ \\
AP & $\mathrm{NR}$ & $5.25^{\mathrm{c}}$ & $22.25^{\mathrm{d}}$ \\
CP & $\mathrm{NR}$ & $3.00^{\mathrm{e}}$ & $40.00^{\mathrm{b}}$ \\
ACP & $\mathrm{NR}$ & $8.00^{\mathrm{a}}$ & $45.00 \mathrm{a}$ \\
\hline
\end{tabular}

Means with the same superscript within the same column are not significantly different following Duncan's Multiple range Test Note: 1 - 24hours; 2 - 48hours; 3 - 72hours, 5 - 120 hours, 7 168hours A - Amylase; C - Cellulase; P - Protease

NR- No reduction

TABLE11 Mycelial growth reduction (mm) of the Aspergillus niger by the partially purified enzymes (singly and in combination) of Trichoderma hamatum

\begin{tabular}{cccc}
\hline & \multicolumn{3}{c}{ Incubation period (days)/mycelial growth $(\mathrm{mm})$} \\
Enzymes & Day 1 & Day 2 & Day 3 \\
\hline A & $\mathrm{NR}$ & $3.25^{\mathrm{d}}$ & $7.50^{\mathrm{g}}$ \\
$\mathrm{C}$ & $\mathrm{NR}$ & $\mathrm{NR}$ & $16.50^{\mathrm{e}}$ \\
P & $\mathrm{NR}$ & $10.00^{\mathrm{b}}$ & $26.50^{\mathrm{c}}$ \\
AC & $\mathrm{NR}$ & $\mathrm{NR}$ & $10.50^{\mathrm{f}}$ \\
$\mathrm{AP}$ & $\mathrm{NR}$ & $7.50^{\mathrm{c}}$ & $21.25^{\mathrm{d}}$ \\
$\mathrm{CP}$ & $\mathrm{NR}$ & $16.00^{\mathrm{a}}$ & $44.00^{\mathrm{a}}$ \\
ACP & $\mathrm{NR}$ & $3.00^{\mathrm{e}}$ & $33.50^{\mathrm{b}}$ \\
\hline
\end{tabular}

Means with the same superscript within the same column are not significantly different following Duncan's Multiple range Test Amylase; C - Cellulase; P - Protease NR- No reduction

Note: 1 - 24hours; 2 - 48hours; 3 - 72hours, 5 - 120 hours, 7 A -

TABLE 12Mycelial growth reduction ( $\mathrm{mm}$ ) of the Fusarium oxysporum by the crude filtrate (singly and in combination) of Trichoderma hamatum

\begin{tabular}{cccc}
\hline \multicolumn{4}{c}{ Incubation period (days)/mycelia growth $(\mathrm{mm})$} \\
Enzymes & Day1 & Day 3 & Day 5 \\
\hline A & NR & $3.50^{\mathrm{g}}$ & $10.50^{\mathrm{g}}$ \\
C & $21.50^{\mathrm{a}}$ & $29.50^{\mathrm{a}}$ & $39.50^{\mathrm{a}}$ \\
P & $14.50^{\mathrm{d}}$ & $17.00^{\mathrm{d}}$ & $22.00^{\mathrm{d}}$ \\
AC & $10.50^{\mathrm{e}}$ & $12.25^{\mathrm{f}}$ & $17.50^{\mathrm{f}}$ \\
AP & $7.75^{\mathrm{f}}$ & 15.25 & $21.75^{\mathrm{e}}$ \\
CP & $19.50^{\mathrm{b}}$ & $25.00^{\mathrm{c}}$ & $28.50^{\mathrm{c}}$ \\
ACP & $15.50^{\mathrm{c}}$ & $29.00^{\mathrm{b}}$ & $33.00^{\mathrm{b}}$ \\
\hline
\end{tabular}

Means with the same superscript within the same column are not significantly different following Duncan's Multiple range Test Note: 1 - 24hours; 2 - 48hours; 3 - 72hours, 5 - 120 hours, 7 168hours A - Amylase; C - Cellulase; P - Protease

NR- No reduction

TABLE13 Mycelial growth reduction ( $\mathrm{mm}$ ) of the Aspergillus terrus by the partially purified enzymes (singly and in combination) of Trichoderma hamatum

\begin{tabular}{cccc}
\hline & \multicolumn{3}{c}{ Incubation period (days)/mycelia growth $(\mathrm{mm})$} \\
Enzymes & Day 1 & Day 3 & Day 5 \\
\hline A & $\mathrm{NR}$ & $0.50^{\mathrm{a}}$ & $5.50^{\mathrm{g}}$ \\
$\mathrm{C}$ & $\mathrm{NR}$ & $\mathrm{NR}$ & $19.50^{\mathrm{d}}$ \\
$\mathrm{P}$ & $3.00^{\mathrm{a}}$ & $12.75^{\mathrm{a}}$ & $25.00^{\mathrm{c}}$ \\
$\mathrm{AC}$ & $\mathrm{NR}$ & $\mathrm{NR}$ & $7.75^{\mathrm{f}}$ \\
$\mathrm{AP}$ & $\mathrm{NR}$ & $8.25^{\mathrm{b}}$ & $12.75^{\mathrm{e}}$ \\
$\mathrm{CP}$ & $\mathrm{NR}$ & $6.50^{\mathrm{c}}$ & $35.50^{\mathrm{b}}$ \\
ACP & $0.50^{\mathrm{b}}$ & $6.50^{\mathrm{c}}$ & $39.50^{\mathrm{a}}$ \\
\hline
\end{tabular}

Means with the same superscript within the same column are not significantly different following Duncan's Multiple range Test Note: 1 - 24hours; 2 - 48hours; 3 - 72hours, 5 - 120 hours, 7 -168 hours A - Amylase; C - Cellulase; P - Protease

NR- No reduction

Aspergilus flavus is a highly aggressive seed colonizer toxigenic plant pathogen[27]. Tables 7 and 10 show the mycelial growth reduction of Aspergilus flavus. Its growth was reduced by the culture filtrates (singly and in combination) with the most significant reduction of $64.50 \mathrm{~mm}$ on the fifth day with amylase and cellulase 
in combination, a most significant reduction of $45 \mathrm{~mm}$ was also observed with the combination of the partially purified amylase, cellulase and protease on the fifth day. The study of the influence of non volatile substances produced by Trichoderma isolates are able to suppress the growth of Aspergilus flavus in vitro by dual culture method with the least growth reduction[27,28].

]Tables 8 and 12 show the growth reduction of Fusarium oxysporum by the crude culture filtrates and the partially purified enzymes respectively. The partially purified enzymes significantly reduced the growth of Fusarium oxysporum. Fusarium oxysporum is known to be both seed and soil borne facultative saprophyte and can survive in the soil up to six years in the absence of a susceptible host[29] . 79.9\% reduction of Fusarium oxysporum has been recorded during the dual culture plate assay of Trichoderma hamatum and Fusarium spp[30]. Trichoderma hamatum has been shown by other works that it can be used to control and inhibit the growth of Fusarium spp[31,32].

The antagonistic activities of the crude culture filtrates and partially purified enzymes of Trichoderma hamatum reduced the growth of Aspergillus niger. The crude culture filtrates (singly and in combination) did not significantly reduced the growth of Aspergillus niger, a reduction of $15.50 \mathrm{~mm}$ was observed on the fifth day with the combination of the three enzymes (amylase, cellulase and protease) as shown in table 9 while the partially purified enzymes significantly reduced the growth of Aspergillus niger with the most significant reduction of $44 \mathrm{~mm}$ observed with the combination of cellulase and protease on the fifth day as shown in table 11. The least reduction shown by the crude culture filtrate could be due the presence of impurities in the culture medium thus inhibiting the antagonist potentials of the enzymes. The efficacy of Trichoderma hamatum, Trichoderma harzianum, Trichoderma viride, Trichoderma longibrachiatum to control and reduce the infection of Aspergilus niger under greenhouse conditions has been reported by Kishore[33].

Apart from Fusarium spp and Aspergillus spp, Trichoderma has also been reported to inhibit the growth of other organisms e.g Phytophthora megakarya[34], Cladosporium herbarum[35], Ceractocystis paradoxa $[36,37]$ e.t.c.

\section{Conclusion}

The combination of all the three enzymes produced yield an hydrolase complex which reduced the growth of the test isolate indicating that the hydrolytic enzymes of Trichoderma can be used to control pathogenic fungi and thus reduce the dependence on synthetic chemicals because it is natural and environmentally acceptable alternative to the existing chemical methods.

\section{References}

[1] B. Hajiegbrari, M. Torabi-Giglou, M. R. Mohammadi and M. Davari, Biological potential of some Iranian Trichoderma isolates in the control of soil borne plant pathogenic fungi, African Journal of Biotechnology 7(8), 2008, 967 - 972.

[2] T. W. Mew and A. M. Rosales, Bacterization of rice plants for controls of shealth and blight caused by Rhizoctonia solani.Phytopathology 76, 1986, $1260-1264$.

[3] G. E. Harman, Overview of mechanisms and uses of Trichoderma spp, Phytopathology 96, $2006,190-194$.

[4] I. Chet, Trichoderma, Application, mode of action and potential as a biocontrol agent of soil borne plant pathogenic fungi, in, I. Chet (ed), Innovative approaches to plant diseases (New York: John Wiley and Sons, 1987), $137-160$.

[5] A. Al-Ghamdi, Y. Molon and S. El-Husseni, Identification of associated fungi recovered from honey bee combs and biocontrol using Trihcoderma spp (in vitro), Alex science Exc.25(4), 2004, 671 - 677.

[6] C. W. Bamforth, The adaptability, purification and properties of exo- $\beta-1,3$-glucanase from fungus Trichoerma reesei, Biochemistry journal 191, 1980, $863-866$.

[7] D. W. Kim and T. S. Kim, Purification of cellulose from Trichoderma viride and properties of its component enzymes, Bulletin of Korean Chemistry Society15(9), 1994, 719 - 724.

[8] A. A. Kulminskaya, K. K. Thompson, K. A. Shabalin, I. A. Sidorenko, E. V. Eneyskaya, A. N. Saval'ev and K. N. Neustroev, Isolation, enzymatic properties and mode of action of an exo-1, 3- $\beta$-glucanase, European Journal ofBiochemistry 268, 2001, 6123 6131.

[9] J. De La Cruz, J. A. Pintoro-Toro, T. Benitez and A. Llobell, Purification and characterization of endo- $\beta$-1, 6-glucanase from Trichoderma harzianum that is related to its mycoparatism, Journal of Biotechnology 177, 1995, $1864-1871$.

[10] P. A. Felse and T. Panda, Production of xylanases by Trichoderma longibrachiatum on amixture of wheat bran and wheat straw: optimization of culture condition by Taguchi method, Enzyme and Microbial Technology 40, 1999, $801-805$.

[11] J. L. Marco and R. C. Felix, Characterization of a protease produced by a Trichoderma harzianum isolate which controls cocoa plant witches broom disease BMC Biochemistry3, 2002,3.

[12] I. Haq, K. Shahzadi, U. Hammed, M. M. Javed and M. A. Qadeer. Solid state fermentation of cellulases by locally isolated Trichoderma harzianum for the exploitation of agricultural byproducts, Pakistan Journal of Biological Sciences 9(9) 1779 - 1782

[13] M. Azin, R. Moravej and D. Zareh, Self - directing optimization parameters for extracellular chitinase production by Trichoderma harzianum in batch mode process, Biochemistry 34, 2007, $563-566$.

[14] W. F. Harriagan and M. E. Mccane, Laboratory Methods in Micribiology, Academic Press London, New York, 342.

[15] S. Ramachandran, A. K. Patel, K. M. Nampoothiri, S.Chandran, G. Szaskacs, C. R. Soccol and A. Pandey, Alpha amylase from a fungal culture grown on oil cakes and its properties. Brazilian Archives of Biology and Technology 47(2) 309 - 317.

[16] M. Mandels and E. T. Resse, Induction of cellulasein Trichoderma viride as influenced by carbon sources and metals, Biology Branch, Pioneering Research Division U. S. Army Quartermaster Research and Development Center Natick, Massachusetts 73, $1956,269-278$ 
[17] M. Mandels, Production and applications of cellulose laboratory procedures adapted from Mary Mandel's production and applications of cellualse, Laboratory procedures handbook, U. S. army materials laboratories, December 1974 by T. W. Jeffries USDA, forest products laboratory, Madison, Wiscosin February 1987.

[18] T. Ekunsami, Laboratory production and assay of amylase from bacteria and fungi, Washington D. C. Newyork.

[19] P. Bernfield, Enzymes of starch degradation and synthesis. Advances in Enzymology 12, 1951, 379 - 481.

[20] S. Martin, K. Anita, H, Martina and V. Ludovit, Induction of secretion of extracellular proteases from Trichoderma viride, Acta Chemica Slovaca 1(1), 2008, $250-264$.

21] M. Kunitz, Crystalline soybean trypsi inhibitor, Journal of General Physiology 29, 1946, 149.

[22] O. H. Lowry, N. J. Rosenbrough, A. I. Farr and R. J. Randall, Protein measurement with the folin phenol reagent, Journal of Biological Chemistry 193, 1951, $265-275$.

[23] N. Sharma, T. C. Bhalla and A. K. Bhatt, Partial purification and characterization of extracellular cellulose from a strain of Trichoderma viride isolated from forest soil, Folia Microbiological 36, 1990, 4.

[24] H. Negash, Isolation, identification of Fusarium xylariodes (Gibberella xylariodes) from Southern Ethopia and its response to fungal biocontrol agents, A thesis submitted to the school of graduate studies of Addis Ababa University in partial fulfillment of the degree of Master of Science in biology [Applied Microbiology].

[25] J. M. Vincent,Distortion of fungal hyphae in the presence of certain inhibitors, Nature 9, $1927,850$.

[26] J. R. Montealegre, I. M. Perez, R. Herrera, P. Silva and X. Besoain, Selection of bioantagonistics bacteria to be used in biological control of Rhizoctonia solani in tomato. Environmental Biotechnology 6, 2003, 1 - 9 .

[27] S. Desai, R. P. Thakur, V. P. Rao and V. Anjaiah, Characterization of isolates of Trichoderma for the biocontrol potential against Aspergilus flavus infection against groundnut. International arachis newsletter 20, 2000, 57 - 59.

[28] J. W. Deacon, Studies on Pythium liogandrum, an aggressive parasite of other fungi, Transaction of the British Mycological Society 66, 1976, 383.

[29] M. P. Haware, Y. L. Nene and M. Natrajan, Survival of Fusarium oxysporium f. sp. Ciceri in soil in absence of chickpea, paper presented in the National Seminar on management of soil borne diseases of crop plants, Proc. Natn. Sem.8 - 10 Jan. 1986. Tamilnadu Agricultural University, Coimbatore, Taminalandu India.

[30] H.Hashmi and A.Ghaffar, In vitro interaction of Fusarium spp with other fungi, Pakistan Journal of Botany $38(4), 1317$ - 1322.

[31] P. S. Nikam, G. P. Japtap and P. L. Sontakke. Management of chickpea wilt caused by Fusarium oxysporum f. sp. Ciceri, African Journal of Agricultural Research 2(12), 2007, 692 - 697

[32] P. Deepak, L. Sarah and G. Lal, Control of wily and blight diseases of cumin through antagonistic fungi under in vitro and field condition, Not. Botany, Horticulture and Agrobotany 36(2), 2008,91 - 96

[33] G. K. kishore, S. Pande, N. J. Rao and A. R. Podile, Biological control of crown rot of groundnut by Trichoderma harzianum and Trichoderma viride, International Arachis Newletter 21, 2001, 39 - 40

[34] A. R. Adedeji, A. C. Odebode and S.O. Agbeniyi, Bioassay of five Trichoderma strains against Phytophthora megakarya (cacao pod rot) in Nigeria, Scientific Research and Essay 3(9), 2008,390 - 394.

[35] M. A. G. Barbosa, K. G. Rectin, M.Menezes and R. R. Mariano, Antagonism of Trichoderma spp on Clasdorium herbarium and enzymatic characterization, Brazilian Journal of Microbiology 32, 2001, $98-104$.

[36] E. I. Eziashi, N. U. Uma, A. A. Adekunle and C. E. Aikede, Effect of metabolites produced by Trichoderma species against Ceratocystics paradoxa in culture medium, African Journal of Biotechnology 5(9), 2006, 703 - 706.

[37] E. I. Eziashi, B. T. Omamor and E.E Odigie, Antagonism of Tichoderma viride and effects of extracted soluble compound from Trichoderma species and benlate solution on Ceratocystic paradoxa, African Journal of Biotechnology 6(4), 2007,388 - 392. 